\title{
MORPHOLOGICAL AND STRUCTURAL CHANGES IN PADDY STRAW INFLUENCED BY ALKALI AND MICROBIAL PRETREATMENT
}

\author{
Karamjeet Kaur *,1 and Urmila Gupta Phutela ${ }^{2}$ \\ 1 The Ohio State University, Columbus Ohio-43210, United States \\ ${ }^{2}$ Punjab Agricultural University, Ludhiana-141004, Punjab, India
}
Article Info:
Received:
8 March 2018
Revised:
13 June 2018
Accepted:
11 July 2018
Available online:
6 August 2018
Keywords:
Paddy Straw
Pretreatment
Alkali
Microwave
Microbial

\begin{abstract}
Paddy straw is a lignocellulosic waste rich in holocellulose (cellulose+hemicellulose) content. It can be used as a good substrate for biogas, bioethanol and biodiesel production. However, the recalcitrant cell wall components i.e. lignin and silica are the main deterrent to efficient utilization of paddy straw. This stringent sheath of lignin and silica does not allow fermenting microbes to access holocellulose. Pretreatment of paddy straw is, therefore, crucial to get rid of lignin and silica. In this context, paddy straw was pretreated with various alkalis viz. $\mathrm{NH}_{3}, \mathrm{Na}_{2} \mathrm{SO}_{3}, \mathrm{Na}_{2} \mathrm{CO}_{3}$ and $\mathrm{NaOH}$ in the current study. All the alkali pretreatments were supplemented with microwave irradiations $\left(720 \mathrm{~W}, 18^{\circ} \mathrm{C}\right)$ for 30 minutes. Paddy straw was also pretreated microbially with Pleurotus florida for 15 days via spawning. Morphological and structural changes in the pretreated paddy straw were visualized via Scanning Electron Microscopy (SEM). The straw turned remarkably fragile with enhanced bulk density and surface wettability after $4 \% \mathrm{NaOH}-30$ min microwave pretreatment. The pretreated straw was also found to lack silicified cuticle layer and lignin sheath which exposes straw sugars (cellulose and hemicellulose) to fermenting microbes.
\end{abstract}

\section{INTRODUCTION}

Cereal straws are abundant, cheap and potential feedstock for biofuel production (Sun, 2010). Rice crop generates straw as much as $23 \%$ of its total weight, which is usually burnt to clear the fields for the next crop. In India, open field straw burning contributes up to $0.05 \%$ of the total green-house gases emission (Gadde et al., 2009). On that account, utilization of paddy straw for biofuel production will help slow down climate change resulting from straw burning besides providing renewable fuel.

However, the main deterrent to paddy straw utilization is the structure of paddy straw which is composed of cellulose, hemicellulose, lignin and silica. Accessing holo-cellulose (cellulose+ hemicellulose) for biofuel production is difficult due to the presence of recalcitrant compounds like lignin and silica (Phutela et al., 2012; Kaur and Phutela, 2016). Hence, pretreatment of paddy straw is essential to access the holocellulose component.

Pretreatment methods are broadly classified as physical, chemical, physico-chemical and biological. In physical pretreatment, biomass is chopped, ground or milled to reduce particle size, exposed to irradiations or subjected to high temperatures or pressure (Fan et al., 1982) to alter the physical and/ or chemical properties. Milling increases methane yield (Delgenes et al., 2002) and hydrolysis rate at the same time. Since there are no inhibitors like furfural and hydroxyl methyl furfural (HMF) formed during milling, it is a good pretreatment method for methane and ethanol production (Hendriks and Zeeman, 2009). However, due to high energy requirements (Ramos, 2003) and continuous rise of energy prices, physical pretreatment methods are not cost effective on their own (Fan et al., 1982) but should be used in combination with other pretreatment methods.

Chemical pretreatment primarily includes chemicals like dilute acid/ alkali, urea etc. Acid pretreatment solubilizes, condensates and precipitates lignin (Liu and Wyman, 2003; Shevchenko et al., 1999). It also causes hemi-cellulose hydrolysis and solubilized hemi-cellulose is then subjected to hydrolytic reactions producing monomers, furfural, HMF and other (volatile) products (Fengel and Wegener, 1984). Due to the formation of these inhibitors, acid pretreatment is more attractive for methane production than ethanol production because methanogens are not affected by compounds like furfural and HMF to a certain concentration and within an acclimatization period. During alkali pretreatment, solubilization, redistribution and condensation of lignin occurs. It also modifies the crystalline state 
of cellulose (Gregg and Saddler, 1996). Change of cellulose structure to a denser and thermodynamically more stable form as compared to the native cellulose is an important aspect of alkaline pretreatment (Pettersen, 1984). Again, loss of fermentable sugars and production of inhibitory compounds make the alkaline pretreatment less attractive for ethanol production but the effect is less severe to methanogens as compared to yeasts (Pavlostathis and Gossett, 1985; Hendriks and Zeeman, 2009). Chemical pretreatments are less energy intensive than the physical methods. However, chemical residues left after pretreatment pose a threat to the environment if not disposed of cautiously.

Physico-chemical methods are a combination of physical and chemical techniques e.g. Ammonia fibre/ freeze explosion (AFEX). In AFEX, an amalgamation of physical and chemical effects induce the cleavage of lignin-carbohydrate complex (Chundawat et al., 2007), hemi-cellulose hydrolysis and cellulose de-crystallization which increases the surface area. These modifications enable complete enzymatic conversion of cellulose and hemi-cellulose to fermentable sugars at low to moderate enzyme loadings (Teymouri et al., 2005). Alizadeh et al. (2005) reported 2.5 fold increase in ethanol yield after AFEX pretreatment of switchgrass. In physico-chemical methods, physical pretreatment primes the substrate for better penetration of chemical. These methods, therefore, have merits over the independent physical and chemical methods (Liu and Wyman, 2005; Kaur and Phutela, 2014).

Biological pretreatment involves the use of lignocellulolytic micro-organisms or enzymes. White-rot, brown-rot and soft-rot fungi are chiefly used for this purpose. Brown rots mainly attack cellulose, whereas white and soft rots attack both cellulose and lignin (Ward et al., 2004). Kirk (1984) stated that if lignin is even partially removed by the chemical or biological means or even if its relationship with the polysaccharides is modified well, the polysaccharide become much more susceptible to the enzymatic degradation. Biological pretreatment is favored over the other pretreatment methods because it is more eco-friendly and does not generate any kind of toxic waste. The slow rate of hydrolysis, substrate and temperature specificity of fungi and enzymes, however, reduce the overall fascination of this method.

In this context, paddy straw was pretreated with different alkalis (viz. $\mathrm{NH}_{3}, \mathrm{Na}_{2} \mathrm{SO}_{3}, \mathrm{Na}_{2} \mathrm{CO}_{3}$ and $\mathrm{NaOH}$ ) in combination with microwaves and a lignocelluloytic fungus viz. Pleurotus florida. In order to enhance the effect of various alkalis, the alkali suspended paddy straw was irradiated with microwaves $\left(720 \mathrm{~W}, 18^{\circ} \mathrm{C}\right)$ for 30 minutes. Alkaline pretreatment $\left(\mathrm{NH}_{3}, \mathrm{Na}_{2} \mathrm{SO}_{3}, \mathrm{Na}_{2} \mathrm{CO}_{3}\right.$ and $\left.\mathrm{NaOH}\right)$ causes swelling of biomass via solvation and swelling, rendering it more accessible to fermenting microbes and enzymes. Microwave irradiations degrade lignin with their high heating efficiency. Microwaves heat the target object directly by applying an electromagnetic field to the dielectric molecules as compared to conduction/convection heating which is based on intramolecular heat transfer (Newnham et al., 1991). Then, the alkali + microwave pretreatment is compared with biological pretreatment (Pleurotus florida) method, the least residue generating method, to assess their efficiencies.

\section{MATERIALS AND METHODS}

\subsection{Alkali pretreatment of paddy straw}

Paddy straw was suspended in various alkalis viz. $4 \%$ $\mathrm{NH}_{3}(\mathrm{v} / \mathrm{v}), 4 \% \mathrm{Na}_{2} \mathrm{SO}_{3}(\mathrm{w} / \mathrm{v}), 4 \% \mathrm{Na}_{2} \mathrm{CO}_{3}(\mathrm{w} / \mathrm{v})$ and $4 \% \mathrm{NaOH}$ $(\mathrm{w} / \mathrm{v})$ and irradiated with microwaves $\left(720 \mathrm{~W}, 18^{\circ} \mathrm{C}\right)$ for 30 minutes in a $1000 \mathrm{ml}$ glass beaker placed inside a microwave oven (MC-2681DS LG Electronics). The solid to solvent ratio was kept constant at 1:10. The pretreated paddy straw was washed with tap water till the washings were clean, colorless and neutral to the $\mathrm{pH}$ paper. The straw was then air-dried and analyzed for change in bulk density, proximate and chemical composition, and surface characteristics.

\subsection{Microbial pretreatment of paddy straw}

Paddy straw was pretreated with lignocellulolytic fungus viz. Pleurotus florida via spawning. To develop the spawn of Pleurotus florida, wheat grains were boiled till tender and excess water was drained off. The boiled grains were allowed to cool and then mixed with $2 \% \mathrm{CaSO}_{4}$ and $4 \% \mathrm{CaCO}_{3}$ powder (per cent w.r.t mass of grains) to avoid clumping of grains. The grains were dispensed into glass bottles $(250 \mathrm{~g} /$ bottle). The bottles were then cotton plugged and autoclaved for 90 minutes at $15 \mathrm{psi}$. After cooling, the bottles were inoculated with $10^{7}$ spores of Pleurotus florida and incubated at $27 \pm 2^{\circ} \mathrm{C}$. To pretreat paddy straw, moist paddy straw (65-70\% moisture) was inoculated with $10 \%$ (w/w) mycelium impregnated grains (per cent w.r.t mass of paddy straw). The inoculated paddy straw was pretreated at $27 \pm 2^{\circ} \mathrm{C}$ for 15 days. After 15 days, pretreated paddy straw was dried and analyzed for change in bulk density, proximate and chemical composition, and surface characteristics.

\subsection{Determination of bulk density of paddy straw}

The density of paddy straw is defined as the mass of paddy straw that can be accommodated in a known volume of a container. The bulk density of dried paddy straw was determined as follow:

$\mathrm{D}=\frac{\mathrm{M}}{\mathrm{V}}$

where $\mathrm{D}=$ density of dried paddy straw

$M=$ mass of dried paddy straw

$\mathrm{V}=$ volume of the empty beaker

The mass of dried paddy straw was determined by the formula:

$\mathrm{M}=\mathrm{M}_{1}-\mathrm{M}_{0}$

where $\mathrm{M}=$ Mass of dried paddy straw

$M_{1}=$ Mass of dried paddy straw occupying beaker + Mass of beaker

$M_{0}=$ Mass of the empty beaker

\subsection{Determination of proximate composition of pad- dy straw}

Proximate composition provides information on the 
combustion characteristics of biomass. It is a measure of total solids (TS), volatile solids (VS), total organic carbon (TOC) and ash. Proximate analysis was done by the standard methods of AOAC (Thiex, 2000). The total solids in the sample (paddy straw) were determined by drying the sample overnight in hot air oven at $70^{\circ} \mathrm{C}$. The dried sample was ignited in a tarred silica crucible in a muffle furnace at $650^{\circ} \mathrm{C}$ for $2 \mathrm{~h}$ to determine ash which is the mineral content in the biomass that remain in oxidized form after combustion. While volatile solids comprise that fraction of biomass that is driven off by heating the sample at a specific temperature for a specific time leaving behind ash. Thus, VS was determined by the formula:

VS (\%) $=100-\mathrm{Ash} \%$

Total Organic Carbon (TOC) was calculated from volatile solids by the formula:

$\mathrm{TOC}=\frac{\text { Volatile Solids }}{1.8}$

\subsection{Determination of chemical composition of pad- dy straw}

Chemical composition gives information about the chemical components like cellulose, hemicellulose, lignin, silica and alcohol/ benzene extractives of biomass. Chemical analysis was done by the standard methods of AOAC (Thiex, 2000) using Fibretech Analyser (FibraPlus-FES08 AS, Pelican). The sequential determination of these components involves the determination of Neutral Detergent Fibre (NDF) and Acid Detergent Fibre (ADF) of biomass.

The concept behind the detergent fibre analysis is that plant cells can be divided into less digestible cell walls (containing hemicellulose, cellulose and lignin) and highly digestible cell contents (containing soluble sugars) (Figure 1). Van Soest (1963) separated these two components by the use of two detergents: a neutral detergent [Sodium Lauryl Sulfate (SLS) + Ethylene Diamine Tetra Acetic acid (EDTA) and an acid detergent - Cetyl Trimethyl Ammonium Bromide (CTAB) in $1 \mathrm{M} \mathrm{H}_{2} \mathrm{SO}_{4}$.

Neutral detergent fibre (NDF) includes those components of biomass which are extractable (not soluble) with SLS+EDTA. Cellulose, hemicellulose, lignin and silica compose the neutral detergent fibre content of paddy straw.

$\mathrm{NDF}(\%)=$ Cellulose + Hemicellulose + Lignin + Silica

While acid detergent fibre (ADF) consists of those components which are extractable (not soluble) with CTAB in $1 \mathrm{M} \mathrm{H}_{2} \mathrm{SO}_{4}$. Because hemicellulose gets solubilized in acid detergent fibre while extraction, so acid detergent fibre is composed of cellulose, lignin and silica only.

$\mathrm{ADF}(\%)=$ Cellulose + Lignin + Silica

Thus, hemicellulose is calculated as the difference between neutral detergent fibre and acid detergent fibre.

Hemicellulose $(\%)=\mathrm{NDF}(\%)-\mathrm{ADF}(\%)$

\subsection{Morphological characterization of paddy straw through Scanning Electron Microscope (SEM)}

The morphological and structural changes in pretreat- ed paddy straw were recorded with scanning electron microscope (Hitachi S-3400N) at Electron Microscopy and Nanoscience Laboratory (EMNL) in PAU, Ludhiana, India. Paddy straw was conditioned and processed to view under SEM. The straw (untreated and pretreated) was dried overnight in a hot air-oven at $70^{\circ} \mathrm{C}$. Then, the oven dried paddy straw was processed for SEM imaging.

The processing involves fixation of the sample (untreated and pretreated paddy straw) with glutaraldehyde, dehydration with increasing alcohol series followed by mounting of the sample on a stainless steel round stub using carbon-tape. Subsequently, the sample is sputter coated with gold $(\mathrm{Au})$ nanoparticles in an ion-sputter coater before being viewed under the Scanning Electron Microscope. The samples were viewed at an accelerating voltage: 15000 Volts, emission current: $123000 \mathrm{nA}$, vacuum: $15 \mathrm{kV}$, magnification: $X 1.50 \mathrm{~K}$, working distance: $12.7 \mathrm{~mm}$.

\section{RESULTS AND DISCUSSION}

Chemical and microbial pretreatment efficacies were evaluated in terms of the changes in bulk density of paddy straw; cellulose, hemicellulose, lignin and silica content; and change in surface structural properties of paddy straw.

\subsection{Change in bulk density of pretreated paddy straw}

The bulk density of paddy straw increased after various pretreatments. Paddy straw became remarkably fragile and lighter in color in the case of $4 \% \mathrm{NaOH}-30$ min microwave pretreatment which has also been reported in one of our previous studies (Kaur and Phutela, 2016a). The increased fragility enhanced the surface wettability of paddy straw. There was $\sim 60 \%$ decrease in the mass of $4 \% \mathrm{NaOH}-30$ min microwave pretreated paddy straw. The bulk density of paddy straw after various pretreatments was found to fall in the range of $85.0 \mathrm{~kg} / \mathrm{m}^{3}\left(\mathrm{NH}_{3}\right.$ pretreated paddy straw) to $210.0 \mathrm{~kg} / \mathrm{m}^{3}$ ( $\mathrm{NaOH}$ pretreated paddy straw). Pretreated paddy straw with enhanced bulk density can be accommodated in a lesser space, if and when needed, which can help storage of huge amount of paddy straw in a limited space (Table 1).

\subsection{Changes in proximate composition of pretreated paddy straw}

The proximate composition of paddy straw remained unaffected after various pretreatments. As shown in Table 2 , total solids varied non-significantly, if at all, after various pretreatments. While a little increase in volatile solids was observed in $\mathrm{Na}_{2} \mathrm{CO}_{3}$ and $\mathrm{NaOH}$ pretreated paddy straw, ash content decreased on the contrary. In point of fact, high volatile solids are good for methanogenesis as more volatile fatty acids are then generated which further enhance the biogas production.

\subsection{Change in chemical composition of pretreated paddy straw}

As shown in Table 3, least NDF (55.9\%) and ADF $(44.2 \%)$ were recorded in $\mathrm{NaOH}$ pretreated paddy straw which indicates that $\mathrm{NaOH}$ dissolved the insoluble fibres 


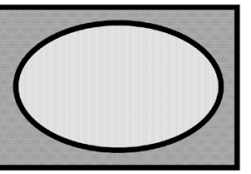

Feed/Forage

Neutral Detergent

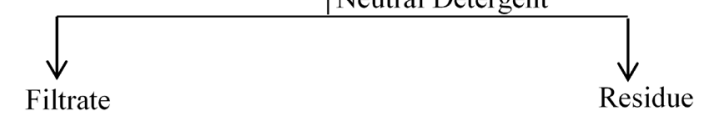

Neutral Detergent Solubles (NDS)

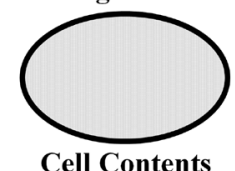

(Soluble Carbohydrates, Proteins, Lipids, Organic Acids, Pectin)

Neutral Detergent Fibre (NDF)

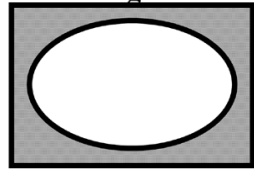

Cell Wall

(Insoluble Fibre and Fibre-Bound Compounds)

Acid Detergent

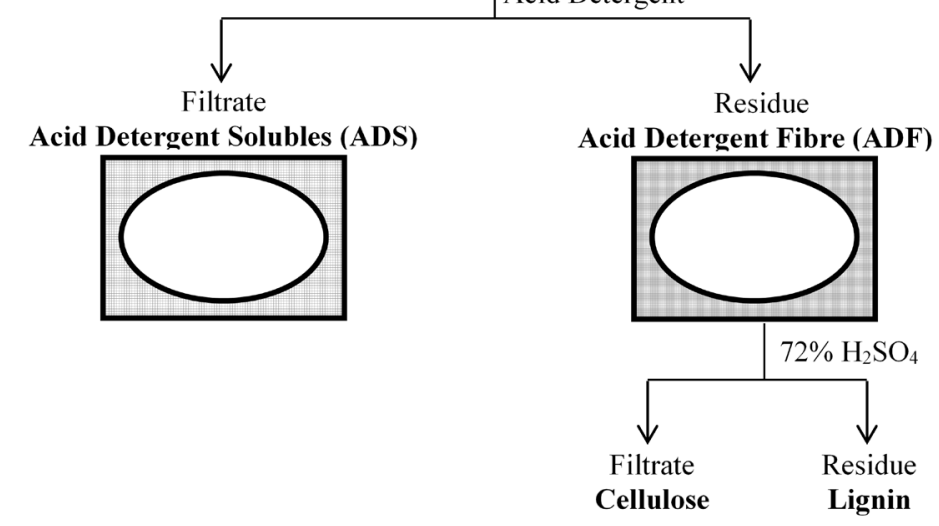

FIGURE 1: Detergent partitioning of fibre fraction according to Van Soest (adapted from Analytical Techniques in Aquaculture Research by Laboratory of Aquaculture and Artemia Reference Center).

and fibre-bound compounds in the cell wall of paddy straw. This then led to the decrease in hemi-cellulose, lignin and silica in the pretreated straw. Interestingly, cellulose content increased to $65.0 \%$ from $45.5 \%$ (control) in $\mathrm{NaOH}$ pretreated paddy straw which is attributed to the removal of recalcitrant components (Kaur and Phutela, 2016a) that makes it freely available and more accessible to fermenting microbes. In $\mathrm{NaOH}$ pretreated paddy straw, hemicellulose, lignin and silica content, respectively, decreased to 11.7, 2.9 and $1.0 \%$ from 23.0, 8.2 and $9.2 \%$ in control. Zhu et al. (2015) reported $92 \%$ decrease in lignin after $10 \%$

TABLE 1: Change in bulk density of paddy straw after pretreatment.

\begin{tabular}{l|c}
\multicolumn{1}{c|}{ Pretreatment } & $\begin{array}{c}\text { Bulk density of dried paddy } \\
\text { straw }\left(\mathbf{k g} / \mathbf{m}^{3}\right)\end{array}$ \\
\hline Control & $81.5 \pm 1.18$ \\
\hline $30 \mathrm{~min}$ microwave & $81.2 \pm 1.57$ \\
\hline $4 \% \mathrm{NH}_{3}-30$ min microwave & $85.0 \pm 1.29$ \\
\hline $4 \% \mathrm{Na}_{2} \mathrm{SO}_{3}-30$ min microwave & $98.0 \pm 1.43$ \\
\hline $4 \% \mathrm{Na}_{2} \mathrm{CO}_{3}-30$ min microwave & $175.5 \pm 1.65$ \\
\hline $4 \% \mathrm{NaOH}_{-}-30$ min microwave & $210.0 \pm 1.78$ \\
\hline Pleurotus florida $(15 \mathrm{~d})$ & $88.0 \pm 1.51$ \\
\hline
\end{tabular}

Control: Untreated paddy straw; Values depicted are mean \pm standard error for $n=3$. sulphuric acid pretreatment of rice straw for $2 \mathrm{~h}$ with no significant loss of cellulose. Pleurotus florida pretreated paddy straw could not surpass the enhanced digestibility that was achieved with $\mathrm{NaOH}$ pretreatment. However, the hydrolyzed straw was still significantly more digestible than the control. Seven fold increase in hydrolysis was observed in fungal consortium pretreated wheat, rice, sugarcane and pea straw (Taha et al., 2015). Cianchetta et al. (2014) noticed minimal cellulose loss in Ceriporiopsis subvermispora pretreated wheat straw. Amongst all the pretreatments, maximum decrease in recalcitrance was recorded in case of $\mathrm{NaOH}$ pretreated paddy straw. The significant and appreciable decrease in silica content makes the pretreated paddy straw a more favored substrate for pyrolysis because slag formation due to melting and crackling of silica will no longer occur in gasifier filled with pretreated paddy straw. At the same time, the $\mathrm{NaOH}$ pretreated highly digestible paddy straw is a great substrate for biogas too as reported in our previous study (Kaur and Phutela, 2016a). The current method worked equally well when upscaled to $100 \mathrm{~kg}$ paddy straw and $1 \mathrm{~m}^{3}$ biogas digester.

\subsection{Morphological and structural changes in pre- treated paddy straw}

Several changes were recorded in the morphological 
TABLE 2: Change in proximate composition of paddy straw after pretreatment.

\begin{tabular}{|c|c|c|c|c|}
\hline \multirow{2}{*}{ Pretreatment } & \multicolumn{4}{|c|}{ Proximate composition of paddy straw (\%) } \\
\hline & Total Solids & Volatile Solids & Ash & Total Organic Carbon \\
\hline Control & $85.4 \pm 1.23$ & $75.6 \pm 1.16$ & $24.4 \pm 1.05$ & $42.0 \pm 0.98$ \\
\hline 30 min microwave & $85.4 \pm 1.15$ & $75.5 \pm 1.22$ & $24.5 \pm 1.34$ & $41.9 \pm 0.93$ \\
\hline $4 \% \mathrm{NH}_{3}-30$ min microwave & $85.4 \pm 1.54$ & $76.0 \pm 1.27$ & $24.0 \pm 1.13$ & $42.2 \pm 1.06$ \\
\hline $4 \% \mathrm{Na}_{2} \mathrm{SO}_{3}-30$ min microwave & $84.9 \pm 1.42$ & $75.9 \pm 1.31$ & $24.1 \pm 1.20$ & $42.2 \pm 1.11$ \\
\hline $4 \% \mathrm{Na}_{2} \mathrm{CO}_{3}-30$ min microwave & $85.4 \pm 1.33$ & $79.1 \pm 1.19$ & $20.9 \pm 1.16$ & $43.9 \pm 0.93$ \\
\hline $4 \% \mathrm{NaOH}-30$ min microwave & $85.7 \pm 1.27$ & $79.9 \pm 1.05$ & $20.1 \pm 1.27$ & $44.4 \pm 1.20$ \\
\hline Pleurotus florida (15d) & $86.1 \pm 1.38$ & $75.9 \pm 1.24$ & $24.1 \pm 1.35$ & $42.2 \pm 1.03$ \\
\hline
\end{tabular}

Control: Untreated paddy straw; Values depicted are mean \pm standard error for $n=3$.

TABLE 3: Change in chemical composition of paddy straw after pretreatment

\begin{tabular}{|c|c|c|c|c|c|c|}
\hline \multirow{2}{*}{ Pretreatment } & \multicolumn{6}{|c|}{ Chemical composition of paddy straw (\%) } \\
\hline & NDF & ADF & Cellulose & Hemi-cellulose & Lignin & Silica \\
\hline Control & $74.5 \pm 1.35$ & $51.5 \pm 1.12$ & $45.5 \pm 1.02$ & $23.0 \pm 0.87$ & $8.2 \pm 0.45$ & $9.2 \pm 0.62$ \\
\hline 30 min microwave & $74.1 \pm 1.40$ & $50.9 \pm 1.09$ & $45.5 \pm 1.31$ & $23.2 \pm 1.02$ & $7.7 \pm 0.64$ & $9.0 \pm 0.41$ \\
\hline $4 \% \mathrm{NH}_{3}-30$ min microwave & $73.9 \pm 1.42$ & $50.1 \pm 1.34$ & $45.8 \pm 1.26$ & $23.8 \pm 1.04$ & $6.3 \pm 0.76$ & $10.0 \pm 0.43$ \\
\hline $4 \% \mathrm{Na}_{2} \mathrm{SO}_{3}-30$ min microwave & $72.2 \pm 1.27$ & $48.7 \pm 1.48$ & $47.6 \pm 1.17$ & $23.5 \pm 1.21$ & $4.8 \pm 0.57$ & $8.3 \pm 0.58$ \\
\hline $4 \% \mathrm{Na}_{2} \mathrm{CO}_{3}-30$ min microwave & $65.8 \pm 1.33$ & $45.5 \pm 1.24$ & $61.8 \pm 1.35$ & $20.3 \pm 1.16$ & $7.2 \pm 0.63$ & $1.9 \pm 0.39$ \\
\hline $4 \% \mathrm{NaOH}-30$ min microwave & $55.9 \pm 1.57$ & $44.2 \pm 1.31$ & $65.0 \pm 1.42$ & $11.7 \pm 0.94$ & $2.9 \pm 0.32$ & $1.0 \pm 0.18$ \\
\hline Pleurotus florida (15d) & $69.1 \pm 1.61$ & $50.6 \pm 1.53$ & $49.5 \pm 1.47$ & $19.5 \pm 1.09$ & $5.6 \pm 0.49$ & $8.1 \pm 0.51$ \\
\hline
\end{tabular}

Control: Untreated paddy straw; NDF: Neutral Detergent Fibre; ADF: Acid Detergent Fibre.

Values depicted are mean \pm standard error for $n=3$.

and surface structural properties of paddy straw. Different pretreatments alter the surface properties of paddy straw in different ways (Figure 2).

In Figure 2-a, the surface of untreated paddy straw was seen intact with phytoliths (P- shown by arrow) and wartlike (W- shown by arrow) structures occupying the surface in an ordered fashion. These well-arranged phytoliths make the straw surface less wettable and add resistance against microbial attack. This makes straw less digestible and non-preferred substrate for feed and fuel. Sarkar and Aikat (2012) have also noticed similar rigidity in the surface of untreated rice straw.

In Figure 2-b, the effect of $4 \% \mathrm{NH}_{3}-30$ min microwave pretreatment is shown on the surface of paddy straw. The waxy cuticular silica layer was found breached. Cracking in the cuticular layer was observed due to the reduction in number of cross-linkages involving ester bonds between the wall polymers (Lam et al., 1992). Wang et al. (2007) have also observed that $\mathrm{NH}_{4} \mathrm{HCO}_{3}$ crack off the cuticular waxy layer of rice stem epidermis resulting in degradation by rumen micro-organisms. Bae et al. (1997) observed that the increased digestibility of $\mathrm{NH}_{3}$ pretreated paddy straw was not due to the degradation of external epidermis of leaf sheath, but was attributed to the weakening of the adhesion between the cuticle and underlying tissues.

As shown in Figure 2-c, tearing of paddy straw surface was recorded in case of $4 \% \mathrm{Na}_{2} \mathrm{SO}_{3}-30$ min microwave pretreatment which results in the removal of lignin (via degradation) from the torn epidermis. The surface degradation in $\mathrm{Na}_{2} \mathrm{SO}_{3}$ pretreatment was more than $\mathrm{NH}_{3}$ pretreatment. Oxygen-sodium sulphite pretreatment has been reported for $95 \%$ delignification with retention of both cellulose and hemi-cellulose (Park et al., 2000).

Partial separation of waxy cuticular layer of paddy straw from the underlying tissues was noticed in $4 \% \mathrm{Na}_{2} \mathrm{CO}_{3}-30$ min microwave pretreatment (Figure 2-d). This exposes the holocellulose content of pretreated straw making it more accessible to the fermenting microbes. Harbers et al. (1982) have also recorded substantial rupture of cuticular surface and its separation from adjacent ground parenchyma in the pretreated wheat straw.

In case of $4 \% \mathrm{NaOH}-30$ min microwave pretreatment (Figure 2-e), paddy straw surface was seen completely torn and tattered due to the dissolution of waxy cuticular silica layer, hence, exposing the inner more digestible components (cellulose and hemicellulose) of paddy straw. $\mathrm{NaOH}$ pretreatment was markedly effective in increasing paddy straw digestibility. After pretreatment, paddy straw turned lighter in color, smoother in texture with increased bulk density and surface wettability. These structural changes were in agreement with the changes in chemical composition of paddy straw whereby nearly $90 \%$ silica removal was recorded. $\mathrm{NaOH}$ cleaves the esterified bonds within the plant cell wall structure thereby reducing the physical enmeshment of cellulose (Chesson, 1981). Van Soest (2006) reported that $\mathrm{NaOH}$ dissolves silicified cuticular layer of paddy straw. Complete delignification of paddy straw along with appreciable silica removal can be achieved using $\mathrm{NaOH}$ (Park et al., 1999) which precipitates silica as sodalite in pulping (Jan and Alexandra, 2006). Papillae, wart-like structures and micro-hairs on the cuticular layer of epidermis were found crimped by $\mathrm{NaOH}$ pretreatment 
(Wang et al., 2007).

In Pleurotus florida pretreated paddy straw (Figure 2-f) fungal hyphae (FH- shown by arrow) were found penetrating into various layers of cell wall of paddy straw which resulted in the degradation of lignin and enhanced straw digestibility. Degradation of cell wall by fungi depends upon the cell wall composition. Some fungi can colonize the entire tissue (like Cyathus stercoreus) whereas others are localized in poor lignified areas like mesophyll (leaf parenchyma) (Karunanandaa et al., 1995).

SEM studies of pretreated paddy straw were in accordance with the chemical make-up of the treated straw which showed enhanced cellulose content in pretreated paddy straw as compared to untreated paddy straw. However, lignin, hemicellulose, and silica, were recorded to reduce significantly.
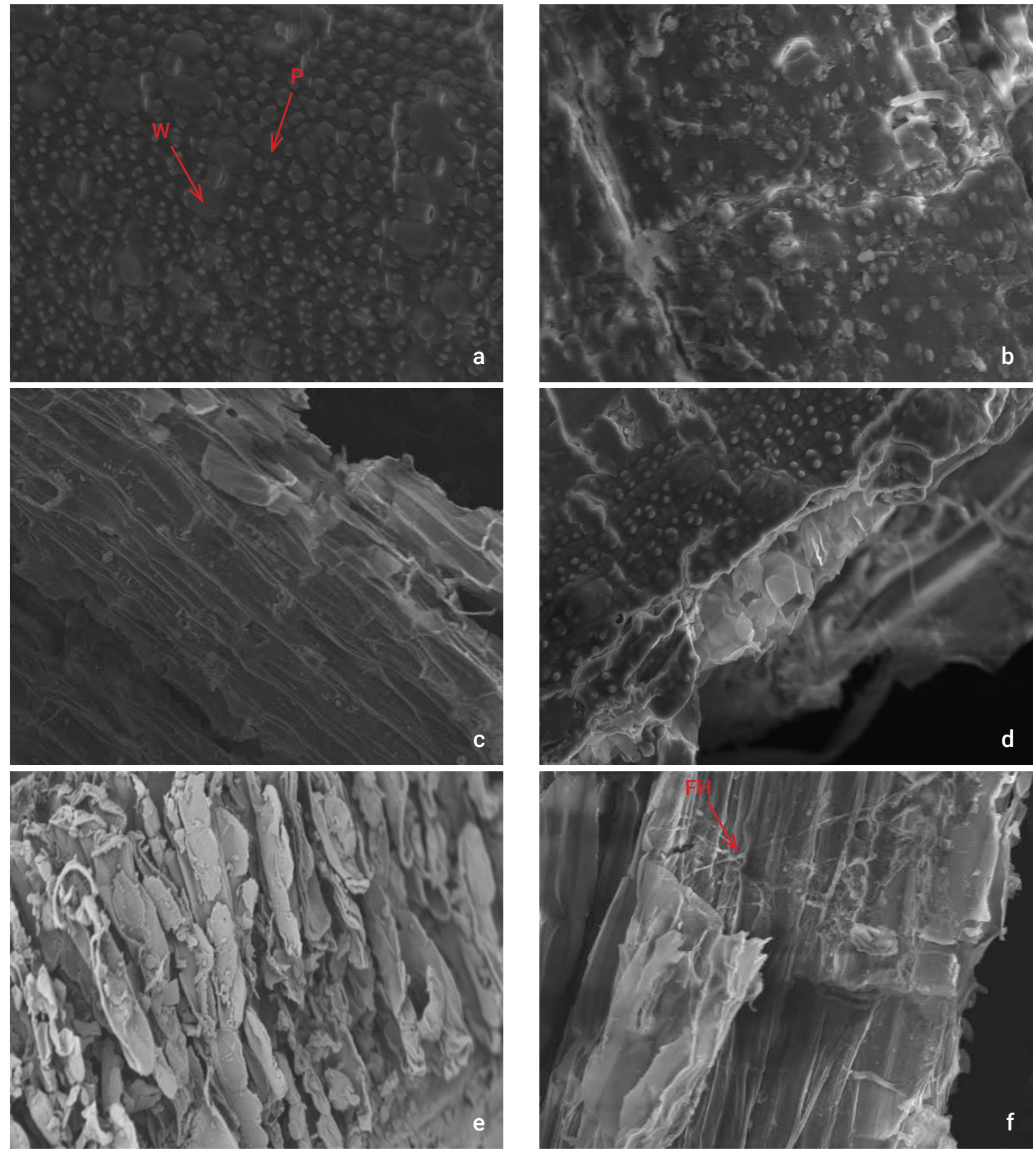

FIGURE 2: Morphological and structural changes in pretreated paddy straw after various pretreatments. a. Control; b. $4 \%$ Ammonia-30 min microwave; c. 4\% Sodium Sulphite-30 min microwave; d. 4\% Sodium Carbonate-30 min microwave; e. 4\% Sodium Hydroxide-30 min microwave; f. Pleurotus florida - P: Phytolith; W: Wart-like structures; FH: Fungal Hypha. 


\section{CONCLUSIONS}

Enhanced bulk density, decreased lignin and silica content, and tattered paddy straw structure indicates that microwave assisted $\mathrm{NaOH}$ pretreatment method is the best amongst the various pretreatment methods investigated in the current study. This pretreatment technique removes more than $90 \%$ silica besides reducing lignin. It is lot quicker with shorter pretreatment period and is straightforward. This method is equally effective when upscaled to $100 \mathrm{~kg}$ paddy straw. However, the wash water generated while washing the pretreated straw is a huge concern which needs to be addressed in future.

\section{REFERENCES}

Alizadeh H., Teymouri F., Gilbert T.I. and Dale B.E. (2005). Pretreatment of switchgrass by ammonia fiber explosion (AFEX). Appl Biochem Biotechnol 121(1-3): 1133-1141.

Bae H.D., McAllister T.A., Kokko E.G., Leggett F.L., Yanke L.J., Jakober K.D., Ha J.K., Shin H.T. and Cheng K.J. (1997). Effect of silica on colonization of rice straw by ruminal bacteria. Anim Feed Sci Technol 85: 165-181.

Chesson A. (1981). Effects of sodium hydroxide on cereal straws in relation to the enhanced degradation of structural polysaccharides by rumen microorganisms. J Sci Food Agric 32: 745-758.

Chundawat S.P.S., Venkatesh B. and Dale B.E. (2007). Effect of particle size based separation of milled corn stover on AFEX pretreatment and enzymatic digestibility. Biotechnol Bioeng 96: 219-231.

Cianchetta S., Maggio B.D., Burzi P.L. and Galletti S. (2014). Evaluation of selected white-rot fungal isolates for improving the sugar yield from wheat straw. Appl Biochem Biotechnol 173: 609-623.

Delgenes J.P., Penaud V. and Moletta R. (2002). Pretreatments for the enhancement of anaerobic digestion of solid wastes In: Biomethanization of the organic fraction of municipal solid wastes. pp. 20128, IWA Publishing.

Fan L.T., Lee Y.H. and Gharpuray M.M. (1982). The nature of lignocellulosics and their pretreatments for enzymatic hydrolysis. Adv Biochem Eng 23: 157-187.

Fengel D. and Wegener G. (1984). Wood: chemistry, ultrastructure, reactions. De Gruyter, Berlin, New York

Gadde B., Menke C. and Wassmann R. (2009). Rice straw as a renewable energy source in India, Thailand and Philippines: Overall potential and limitations for energy contribution and green-house gas mitigation. Biomass Bioener 33(2): 1532-1546.

Gregg D and Saddler JN (1996) A techno-economic assessment of the pretreatment and fractionation steps of a biomass to ethanol process. Appl Biochem Biotechnol 57-58: 711-727.

Harbers L.H., Kretner G.L. and Davis G.V. (1982). Ruminal digestion of ammonium hydroxide treated wheat straw observed by scanning electron microscopy. J Anim Sci 54:1309-1319.

Hendriks A.T.W.M. and Zeeman G. (2009). Pretreatments to enhance the digestibility of lignocellulosic biomass. Bioresour Technol 100: 10-18.

Jan P. and Alexandra P. (2006). Process of removing silica from cellulosic material. U.S. Patent, 20060225852.

Karunanandaa K., Varga G.A., Akin D.E., Rigsby L.L. and Royse D.J. (1995). Botanical fractions of rice straw colonized by white-rot fungi: Changes in chemical composition and structure. Anim Feed Sci Technol 55:179-99.

Kaur K. and Phutela U.G. (2014). Improving paddy straw digestibility and biogas production through chemical-microwave pretreatments. Agric Sci Digest 34 (1): 8-14.

Kaur K. and Phutela U.G. (2016). Sodium carbonate pretreatment: An approach towards desilication of paddy straw and enhancement in biogas production. Paddy Water Environ. 14 (1): 113-121.

Kaur K. and Phutela U.G. (2016a). Enhancement of paddy straw digestibility and biogas production by sodium hydroxide-microwave pretreatment. Ren. Energy 92: 178-184.
Kirk T.K. (1984). In: Nicholas DD (Ed.) Wood determination and its prevention by preservative treatments, University Press, New York Syracuse, pp. 149-181.

Lam T.B.T., liyama K. and Stone B.A. (1992). Cinnamic acid bridges between cell wall polymers in wheat and phalaris internodes. Phytochem 31: 1179-1183.

Liu C. and Wyman C.E. (2003). The effect of flow rate of compressed hot water on xylan, lignin and total mass removal from corn stover. Ind Eng Chem Res 42: 5409-5416.

Liu C.G. and Wyman C.E. (2005). Partial flow of compressed hot water through corn stover to enhance hemicellulose sugar recovery and enzymatic digestibility of cellulose. Bioresour Technol 96(18): 1978-1985.

Newnham R.E., Jang S.J., Xu M. and Jones F. (1991). Fundamental interaction mechanisms between microwaves and matter. In: Clark DE, Gac FD and Sutton WH (Eds.) Microwaves: Theory and Application in Materials Processing (Ceramic Transactions), vol. 21, America Ceramic Society, Westerville, Ohio, USA.

Park S.Y., Keiichi K., Yuji M., Gyosuke M. and Kenji I. (1999). Kinetic comparison between delignification and silica removal during alkaline pulping of rice straw. Jpn TAPPI J 53(11): 1492-1499.

Park S.Y., Koda K., Matsumoto Y., Meshitsuka G. and liyama K. (2000) Oxygen weak base pulping of rice straw with minimum silica removal. Jpn TAPPI J 54(9): 1245-1251.

Pavlostathis S.G. and Gossett J.M. (1985). Alkaline treatment of wheat straw for increasing anaerobic biodegradability. Biotechnol Bioeng 27: 334-344

Pettersen R.C. (1984). The chemical composition of wood. In: Rowell R $M$ (ed) The chemistry of solid wood, Advances in Chemistry Series, Vol. 207, pp.984, American Chemical Society, Washington, DC.

Phutela U.G., Kaur K., Gangwar M. and Khullar N.K. (2012). Effect of Pleurotus florida on paddy straw digestibility and biogas production. Int J Life Sci 6 (1): 14-19.

Ramos L.P. (2003). The chemistry involved in the steam treatment of lignocellulosic materials. Quim Nova 26(6): 863-871.

Sarkar N. and Aikat K. (2012). Alkali pretreatment of rice straw and enhanced cellulose production by locally isolated fungus Aspergillus fumigatus NITDGPKA3. J Microbiol Biotechnol Res 2(5): 717-726.

Shevchenko S.M., Beatson R.P. and Saddler J.N. (1999). The nature of lignin from steam explosion/enzymatic hydrolysis of soft wood. Appl Biochem Biotechnol 77-79: 867-876.

Sun R.C. (2010). Cereal straw as a resource for sustainable biomaterials and biofuels, Elsevier, Amsterdam, The Netherlands.

Taha M., Shahsavari E., Al-Hothaly K., Mouradov A., Smith A.T., Ball A.S. and Adetutu E.M. (2015). Enhanced biological straw saccharification through co-culturing of lignocellulose degrading microorganisms. Appl Biochem Biotechnol 175: 3709-3728.

Teymouri F., Laureano-Perez L., Alizadeh H. and Dale B.E. (2005). Optimization of the ammonia fiber explosion (AFEX) treatment parameters for the enzymatic hydrolysis of corn stover. Bioresour Technol 96: 2014-2018.

Thiex N.J.W. (2000). Animal feed. In: Official methods of analysis, $17^{\text {th }}$ edn. Association of Official Analytical Chemists (AOAC), Gaithersburg.

Van Soest P.J. (2006). Rice straw, the role of silica and treatments to improve quality. Anim Feed Sci Technol 130(3-4): 137-171.

Van Soest P.J. (1963). Use of detergents in the analysis of fibrous feeds. II. A rapid method for the determination of fiber and lignin. $J$ Assoc Official Anal Chemists. 46: 829-835.

Wang J.K., Liu J.X., Li J.Y., Wu Y.M. and Ye J.A. (2007). Histological and rumen degradation changes of rice straw stem epidermis as influenced by chemical pretreatment. Anim Feed Sci Technol 136(1-2): 51-62.

Ward G., Hadar Y. and Dosoretz C.G. (2004). The biodegradation of lignocellulose by white-rot fungi. In: Arora DK and Dekker M (Eds.) Fungal Biotechnology in Agricultural, Food and Environmental Applications, New York, pp. 393-407.

Zhu S.D., Huang W.J., Huang W.X., Wang K., Chen Q.M. and Wu Y.X. (2015). Pretreatment of rice straw for ethanol production by a two-step process using dilute sulfuric acid and sulfomethylation reagent. Appl. Energy 154: 190-196. 